\title{
EDUCATOR IN THE PRESPECTIVE OF ISLAMIC AND WESTERN EDUCATION THEORY
}

\author{
Abdul Basir \\ Study Program of Islamic Education, Faculty of Tarbiyah and Teacher Training \\ Universitas Islam Negeri Antasari Banjarmasin \\ Email: abdulbasir@uin-antasari.ac.id \\ Website: http://jurnal.uin-antasari.ac.id/index.php/jtjik \\ Received: 5 February 2020; Accepted: 30 June 2020; Published: 30 June 2020
}

\begin{abstract}
Educators take as an important rule in educational system. They are the ones who are responsible for the students in achieving their educational goals. Basically, there is no difference concept of educators in both Islamic and Western Education. However, Islam has broader perspectives compared to the Western one, since in Islam Allah is believed as the first and foremost teacher or educator. Then, this is continued by the Prophet Muhammad as a recipient of revelations from Allah, and then it is inherited to the Islamic Scholars and even parents to educate their followers, children, and all family members. The position of educators is highly appreciated according to Islamic Education, since the source of the knowledge taught to the human is directly from Allah the Almighty God. Therefore, the nature of educators should become role models which can be taken as a good example for the students in order to improve the quality of theit faith and piety. Thus, the terms and conditions for an educator are s/he must be an adult, has good personality and character, has broaden knowledge and skills, and also good attitudes and consistency based on Islamic taughts.
\end{abstract}

Keywords: educator; position; nature; requirements and role

\section{INTRODUCTION}

The essence of educator is to educate and also teaches correspond to the knowledge he has (Ramli, 2015). The essence of educator in Islamic education's perspective is the people who are responsible to all the learners' potential, either affective, cognitive, or psychomotor correspond to the Islamic teaching values (Muhammad, 2014). Cognitive domain makes the learners clever in their intellectual. Affective domain makes the learners have a polite attitude and behavior. And psychomotor domain makes the learners have a skill in doing the activities effectively and efficiently. Different with the modern view in this reformation era that the educator is a professional who is doing the planning, implementing, and evaluation in a learning, while for the university is doing the university's tri dharma, which is including teaching, research and community service. (UU Number 20 Year 2003 Article 39); (Suparlan, 2006). Therefore, it is clear that the educator is a professional position (Soetjipto, 2009) that has certain characteristics which should be fulfilled by the educator. Because of that, the educator is

really glorified and respected because of the true educator is the prophets' heir. (Abu Daud: Chapter 11 p. 34, Maktabah Syamilah). 
Tarbiyah: Jurnal Ilmiah Kependidikan

Vol. 9 No. 1. January - June 2020 (42-50)

DOI: http://dx.doi.org/10.18592/tarbiyah.v9i1.3471

\section{RESEARCH METHOD}

The purpose of the research is to delve the data about essence, position, characteristics, requirement, and the role of education reviewed in the Islamic and Western education's perspective. This research is a library research which is delve the data from books, articles especially which has a relevance with the researched topic. The type of research is descriptive qualitative, that is the research that explain the data narratively appropriate to the result of research that researcher gets. (Moleong, 1989).

\section{FINDING AND DISCUSSION}

\section{The Essence of Education}

Education is a process of learning activity that carried out by, from and for human. (Khasinah, 2013). A human who fielded himself in education is called educator. Educator is someone who feels have a responsible in educate (Saputra, 2015). Educator in English is also called as a teacher. Teacher can be at school or house, which known as a tutor. In Arabic, educator is known as ustadz, mudarris, mu'allim, mursyid and mu'addib. Academically, the highest level of educator known as a professor. From this explanation, it can be seen that the educator is someone who teaches with the tasks of educating human, whether as trainer, writer, poet, teacher, lecturer, that has a functional in carrying out the activity in providing knowledge, skills, education and etc. (Nata, 1997).

Educator is someone who has a responsibility in education. (Tafsir, 2006). However, the meaning of educator is different between Islam and Western. Educator from Islamic meaning is broader than Western meaning. Educator in religion has a meaning responsibility, not only for himself but also for anyone else with the aim of togetherness of the people. (Ramayulis, 2008).
Sayyed Muhammad al-Naquib al-Attas, as the Islamic figure said that educator as Murabbi, Mu'allim and Muaddib. Murabbi means physical and spiritual care. Nurturing is raising their child with Islamic values. Whilell, Mu'allim is the educator's task in providing a knowledge to others. And there is Muaddib is from the word addaba, yuaddibu correspond to Rasulullah SAW's hadith which has meaning, "My God educates me, then He gives me the best education." In AlQur'an ta'dib is not found in Al-Qur'an, but only from Nabi SAW's hadith and in dhaif (weak) hadith. (Basir, 2015). However, muaddib is broader meaning than Muallim. Muallim only focus on the teaching system while muaddib is broader. (al-Attas, 1980). Next, educator is also called Mursyid. Mursyif is the educator who has thariqat knowledge so he became as a role model for his students. (Anas, 2017). Therefore, educator in Islamic menaing is has a responsibility not only for himself but also to others. While, education in Western concept, educator is identical to teacher, tutor, instructor, lecturer, and trainer. That is someone who is transferring a knowledge to someone else to reach the desire goal.

Basically, the concept of education between Islam and Western have a similarity. Swift D.F in his book "Sociology of Education" which stated by some experts such as Plato, Aristoteles, and others. Plato agreed with Socrates' opinion that education is for forming a good morals. While, Aristoteles said that education is more political so that education can give a happiness of people's lives. (D.F, 2011).

From the meaning of education above, the educator in Western concept should be someone who is professional, proficient and has a high knowledge in delivering the knowledge to students. The educator according to Islamic concept is broader, that is the educator's job is a mandate from Allah 
Tarbiyah: Jurnal Ilmiah Kependidikan

Vol. 9 No. 1. January - June 2020 (42-50)

DOI: http://dx.doi.org/10.18592/tarbiyah.v9i1.3471

SWT so that students become the person of faith and have a good morals. So, educator is not only transferring knowledge until students are skilled as the concept of educator from Western knowledge.

The basic different between Islamic and Western concept from the type of education are:

a. Allah SWT. The first educator in the world is Allah SWT. Allah has the highest authority which no one can match Him as almighty all creators. Knowledge is not separated from Allah, so that an educator has the highest position in Islam (Ali, 2014). The words of Allah in the Qur'an talk a lot about Allah as an educator which revealed to the Prophet Muhammad SAW. This vast knowledge is owned by Allah which can be seen in His word as $\mathrm{He}$ teachers Adam to the existing objects. Afterwards, told it to the Angels, then $\mathrm{He}$ said: "Mention to Me the name of the objects if you are really the right person" (Q.S. Al-Baqarah:31). The words of Rasulullah SAW, "My God has taught me until makes me the best person in education". Based on the verse and the hadith above, it can be understood that Allah SWT as the educator to human being.

b. Prophet Muhammad SAW. The prophet is as a mu'allim or educator. Muhammad who received a revelations from Allah to convey it to all of humanity. His position is appointed directly by Allah SWT as the educator. The portrait of Rasulullah's personality as the human who as a noble character which during his lifetime he taught the generation of Islam. Rasulullah was made as a role model of a great human being with a very noble character. His character and personality are very worth to be followed by the generation of Islam (Amirudin M. F., 2016). Statutory regulations about teacher competency that is pedagogic competency, personal, professional and social has a very clear red thread to the mandatory qualities owned by Rasulullah, which is siddiq. Siddiq to the behaviroe of an educator is like behavior and words is accordance with his reality and behavior. Siddiq (honest) is also same with personality competence (Anas N., 2017). Then, Amanah (believable). It is same as the characteristic of social competency which include the interaction of communication, cooperate, and associate (Anas N., 2017). Tablilgh means deliver which is same as professional competency. This competency is closely related to the evaluation as the purpose in learning (Anas, N., 2017). The next is Fathanah. It means clever. Fathanah can be likened to the pedagogic competency. To reach the purpose of the learning then in curriculum application should be careful in choosing a learning method. (Anas N., 2017).

c. Ulama (Theologian). The theologians are the heir to the prophets. Among the porpositions (dalil) to this state is Q.S. AlFathir verse 28. The terms of theologian is called in Al-Qur'an as the person who is really afraid (khasyyah) to Allah SWT. In the prophet's hadith which there is in Sunan Abu Dawud, is said that theologians are the prophets' heir (al- 'ulama' waratsat al-anbiya'). Beside the word theologian, Al-Qur'an said some terms that identical to theologian (ulama) that is al-'alimun (knowledgeable people), ulu alalab (intelligent people), ulu al-nuha (intelligent people), ulu al-'ilm (knowledgeable people) and utu al-'ilm (a person who is given a knowledge). (Maisyarah, 2019). Educational institution at school is called teacher, either at kindergarten, madrasa, primary school, junior high school, senior high school, until lecturer in college. Teacher has a job 
Tarbiyah: Jurnal Ilmiah Kependidikan

Vol. 9 No. 1. January - June 2020 (42-50)

DOI: http://dx.doi.org/10.18592/tarbiyah.v9i1.3471

to educate as a mandate from parents and also everyone who needs to educate a child. Teacher as the holder of the mandate, has a full responsibility at school to develop a students' skill correspond to the Islamic values. The purpose of the educator is to implement his job as a Khalifah (leader) is to giving an awareness to the students (Amirudin M.F., 2016).

d. Parents. Family is the first and main education for a child (Maghfiroh, 2019). A child naturally in his early life is in the middle of his parent. Starts form his family, a child is recognize education. In Al-Qur'an, parent is as the teacher for their child. The education that taught by parent, from religion value, ordered their child to do prayers, patient in facing an affliction. That is why parent is called as "natural educator" that is the educator that created by Allah to be an educator. Parent's education, has a result of a pious child who always kind, has affection and always pray for his parent that they get an affection from Allah SWT (Basir, 2015, p. 14). This opinion is based to Q.S. al-Isra' verse 24 and Q.S. Luqman verse 12-19. Q.S al-Isra' verse 24 implies that parents have a job to educate, nurture and taking care their children when they are child. In Q.S Luqman verse $12-19$, is explained that Luqman is a person who get wisdom from Allah SWT., and then Luqman educated his child about monotheism (ketauhidan) and reject polytheism, kind to parents, pray, amar ma'ruf nahi munkar, patient, simple and lower the voice. Therefore, alQur'an affirms that Allah SWT is mandating parents to educate their children (Maisyaroh, 2019).

From the explanation before. It can be understood that the difference education concept according to Islam and Western is really clear. In Western is not know at all that God and Prophets are the main educator. While, the similarity is that parents and teachers are as the educator is the concrete empirical cases. But, the different in Islam that that thing is a mandate from Allah SWT to them.

\section{The Position of Education in Islamic and Western Education}

The highest reward in Islamic teaching is an educator, because the knowledge that he got is from God (Ali, M, 2017 : 85). Egyptian modern poet explain the position of teacher:

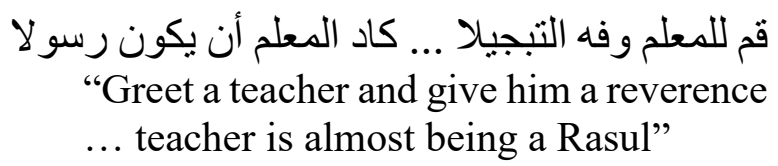

An Islamic reward towards the educators as a very valued the position, so that Allah elevate the degree to the faithful and knowledgeable people (Q.S. Al-Mujadalah : 11). The hadith of Rasulullah explain that the best of person is a person who learns al-Qur' an and teaches it (Bukhari).

The words of Allah and the hadith give us the meaning about the position of educator. The educator with his knowledge which all is from Allah, so that can make a human close to Allah. The ability bring forth the theories to the benefit of humanity.

A reward like this ofcourse there is only in Islamic teaching. A modern Western does not have a concept like this. Because in Western, the interaction between teachers and students is restricted in liberal social life. Where teacher on duty in transferring the knowledge they have. While, the students receive without religious emotional bond. So that, freedom is a basic rights that they uphold. A reward for them is depend on the professionalism which is the material that they get in world life. Different to Islamic concept, as Al-Ghazali expressed in Ihya'ulumuddin that quoted by Al-Abrasyi said: a knowledgeable person and works with 
his knowledge, then he works in education field. He chooses on honorable job, but has manner and politeness in doing his job. AlGhazali, for human who have a high position with practicing the knowledge he knows. He is considererd have a kingdom of heaven which can light the nature, the light for himself. He is like a parfume that can give a fragrance to others. To who choose a job to teach then he chooses a noble job so that he is better maintain his behavior or his obligation. (Fahmi, 1979). The concept of educator's position like this ofcourse is unknown in Western education. In Western, the thing that is more preferred is a liberalization to reach a satisfaction and enjoyment of life in the world. So that a teachers are directing their students to reach the purpose that they expect.

\section{The characteristic of Educator in} Islamic and Western Perspective

According to Islamic perspective, educator has a different from one to the others. The characteristics that are owned become a trait, the character that fully unites to himself, so that it becomes a totality to his words and action. An-Nahlawi divides the characteristic of educator which consist of rabbaniyah character and nature. That character is realized from a behavior such as sincere, has a responsibility, patient, and honest. Those characters are equipped with knowledge and the willingness to study the related knowledge. The method, be able to manage the class well, be firm in acting and professional. (Nizar, 2005).

According to Muhammad Athiyah alAbrosy, an educator should have seven characteristics, among them are, zuhud, pure souled, sincere and know the students' talent. Zuhud is a character which do not use material in doing its job. A pure souled is a soul that avoid from a bad nature, either physical or spiritual. Sincere is doing a job with having a forgiveness, fatherhood which means the character that position themselves as a protector and think about students' future. A teacher should know the students' talent so that the taught method is appropriate with the stage of child's moral development. (AlAbrasyi, 1975).

The characteristics of educator in Western concept according to the writer is not really different with the Islamic concept. Basically it is same. But, the thing that distinguish between the concepts is on the religious normative concept. Such as living in zuhud, sincere, seeking for a blessed and reward from Allah and has a noble morals. While, the other is universal. It means either Islam or Western should have the characteristics above.

\section{The Requirements and The Role of Educator in Islamic and Western Education}

The requirements of an educator according to Islamic education concept, among them are maturity, has a good norm, has an extensive knowledge, skill and attitude (has an attitude and a good determination) (Roysadi, 2004). A teachers should do their job and obligation as the teacher with remembering Allah's warning, so that they do not crazy of the wealth, rank, position but make his knowledge becomes other people's pride. (Ramayulis, 2005). Next, teachers are take a step away from abject livelihoods that can be a vilification and vilify a symbol for themselves as a teacher. (Ramayulis, 2005).

A teachers should be diligent in doing an order and avoid a prohibition appropriate to their religion. His moral is well preserved, and avoid the association that cause a bad morals. Teachers should filling their time well and useful. Teachers feel inferiority if there is a fail in themselves. They did not feel ashamed if they blamed as their professionalism as a teacher. (Ramayulis, 2005).

Next, for the teachers before go to school, should take ablution (wudhu) to get 
Tarbiyah: Jurnal Ilmiah Kependidikan

Vol. 9 No. 1. January - June 2020 (42-50)

DOI: http://dx.doi.org/10.18592/tarbiyah.v9i1.3471

rid of a small turd (hadats) and using a well dress as a symbol of glorify the shari'a. When they are out from house, they did not forget to pray, $d z i k r$, in the purpose that the knowledge delivered be a mandate to themselves and the students that learn the knowledge from them. A teachers should be fair and not differentiate social status of the students and do not forget to always watching from the students' intellectual stage. (Ramayulis, 2005).

While, the educator in Western concept is an educational staff "qualified as a teacher, lecturer, counselor, learning guardian, wisyaswara, tutor, instructor, facilitator" and the other who participate for organization of education. (Assegaf, 2011). Teacher as a student advisor and also a problem solving or helping a students who have a problem in education, either internally or externally. As an educator knowing, understanding a problem that students face. (Assegaf, 2011).

Basically, there is no basic difference between Islamic and Western education concept about educator requirements. But, in Islamic education concept is more emphasis on the forming of intellectual and moral and oriented to the purpose of happiness in the world until the afterlife. While in the Western education concept about the educator's requirement is more emphasis on the problem solving which student faces to the world success only. And not oriented in the afterlife. Because the affairs of the afterlife are left to each person.

The role of education in the life with technological development, will not able to replaced by educational media, because educator is a living model or ruh al ustadz that is more important from all the methods, materials and media. This value is only can be found in the educator personality in Islamic concept. The educator will not be able to found the success if not educated by Islamic educator.
More than that, basically an education has a positive purpose so that it becomes a habit of the teaching that taught by education. The cognitive domain level is able to differentiate which one is food and which one is bad, then able to feel (affective domain) the good value and want to do it (psychomotor domain). The habituation process will not be able to going well without a help from the educators and the people who is involved in education responsible.

Islamic education concept fro the role of educator is appropriate to the islami value can be a base in doing a prophetic job and professionalism of educator. Rasulullah as the role model for Islam in teaching. Rasulullah is not only carry on a noble mission from Allah but as a transmitter of revelation from Allah. $\mathrm{He}$ as the educator is not only read or deliver, but also purify, cleanse a soul and develop a personality. (Q.S. Al-Jumu'at : 2). While, teaching is delivering from the purpose of students as a human and also as a leader. (Q.S. Al-Baqarah : 31), and for subserve, pray to Allah SWT (Q.S. Adz-Dzariyat : 56).

The role of educator gets a high reward in Islam which nothing in the Western concept. Rasulullah as the heir of knowledge with teaching Islamic values to generation after generation so that Rasulullah SAW is more glorify an educator than an 'abid (worship expert). Rasulullah SAW also said in one of his hadith which the meaning is "the virtue of an educator than a worship expert is like my virtue compared to the lowest person (the position) among you". Then, Rasulullah SAW said again: "Surely Allah, the angels, the inhabitants heaven and earth, even ant in its hole and fish is also pray to the person who teaches a good to humankind" (Turmidzy).

Imam al-Ghazali (died in 1111), gave a rational argumentation why the educator profession is more glorify than the other. He said: "The virtue of a profession or a job can seen from the object of the profession task. A 
Tarbiyah: Jurnal Ilmiah Kependidikan

Vol. 9 No. 1. January - June 2020 (42-50)

DOI: http://dx.doi.org/10.18592/tarbiyah.v9i1.3471

goldsmith is seen as more glorify if he is compared to the coppersmith, because a gold is more glorify than a copper. The position of an educator is higher than the other profession, because the thing that being as a task target object is most valuable things in human, which is the heart, while a human is the most noble creature. That is why the educator profession is the noblest profession, one level under prophecy." (Ghazaly).

Therefore, teacher can not be replaced by the technology such as radio, tape recorder, internet, or the most modern computer. Here is the different with the education in Western which is in Western education, media can be a substitute of teacher in exploring a knowledge.

In Islamic education, there are a background element of the educator's role such as attitude, value system, feeling, motivation, habit and exemplary that expected from the result of a leaning process which can not be achieve except through the educator's presence with a code of ethics or the morals they owned.

A teachers have a big responsibility and also a role model for students. At the school, teacher becomes a benchmark for students, while in society, teacher becomes a role model and gets a high and honorable position.

A role of Islamic education as an operational concept is an internalization and transformation process from Islamic values in developing a nature and basic ability that students have with the purpose to reach a balance in various aspects of life. In connection with that, Al-Nahlawi states that a role of teacher should imitate the role of Rasulullah which are study and develop divine knowledge. Thus, the muslim educator's code of ethic that put forward by the Islamic classic and contemporary theologian. And ofcourse, this is also differentiate the concept of educator or teacher in Western education. However, the writer is aware that this writing ofcourse very subjective apologist, but that is the nature of educator concept according to Islamic teaching.

\section{CLOSURE}

From the explanation above, it can be concluded that educator is a very important component in education system. According to Islamic or Western view, in this thing there is no different. Because an educator in its essence which deliver a students to the predetermined purpose. An educator has a very noble position, therefore the educator is made as a role model for the students whether from an attitude, moral, also can guide and motivate a students so it can carry out a better future. The position of education in Islam is different with Western concept. Because in Islamic concept, it is a mandate from Allah SWT and not only a profession as in the Western education. Because of that the final purpose of Islamic education to reach a happiness in the world and the afterlife, which only to reach a happiness. While in Western education concept, there is no final purpose to reach an afterlife happiness, there is only to reach a happiness in the world.

Thus, this article writer conveys, hopefully it can have a benefits for the readers and the observer in the filed of education. It is still has many lacks, so writer is really expects the suggestion. May Allah SWT gives us His guidance. Amin.

\section{REFERENCES}

'Athiyah, a.-A. M. (1969). At-Tarbiyah alIslamiyah wa Falasifatuha. Beirut: Dar al-Fikr.

A.M., S. (2010). Interaksi dan Motivasi Belajar Mengajar. (Jakarta: PT. RajaGrafindo Persada.

al-Abrasyi, M. A. (1975). Muhammad AthiyAlTarbiyah al-Islámiyah wa Falãs!fatuha. Mesir: Isa al-Babi al-Halabi. 
Tarbiyah: Jurnal Ilmiah Kependidikan

Vol. 9 No. 1. January - June 2020 (42-50)

DOI: http://dx.doi.org/10.18592/tarbiyah.v9i1.3471

Al-Attas, S. M.-N. (1980). The Concept Of Education in Islam. Kuala Lumpur: Muslim Youth Men Of Malaysia ABM.

Ali, M. (2014). Hakikat Pendidik Dalam pendidikan Islam. Jurnal Tarbawiyah Volume 11 Nomor 1 Edisi Januari-Juli 2014, 85.

al-Kailani, M. '. (1986). al-Fikr at-Tarbawi 'Ind Ibn Taimiyah. Madinah: Maktabah Dar at-Turats.

Amirudin, M. F. (2016). Analisi Filosofis Hakikat Pendidik Dalam Islam. eL-Ghiroh. jurnal.staibsllg.ac.id, 11(2), 49-65.

Anas, N. (2017). "RASULULLAH SEBAGAI PENDIDIK PROFESIONAL. " Pendidikan Islam 1.2, 137-147.

Ar-Razy. (n.d.). Tafsir Ar Razy. Dalam maktabah Syamilah.

Assegaf, A. (2011). Filsafat Pendidikan Islam. Jakarta: Rajagrafindo Persada.

Basir, A. (2015). Model Pendidikan Keluarga Qur'ani . Banjarmasin: Antasari Press

Bukhary, a. (n.d.). Jami al Shahih. dalam Maktabah Syamilah.

D.F, S. (2011, 01 Senin). Sociology Of Educatin. Retrieved Juli Senin, 2019, from http://atehmies.blogspot.com: http://atehmies.blogspot.com

Daud, A. (-). Sunan Abi Daud. -: Maktabah Syamilah.

Fahmi, A. H. (1979). Sejarah dan Filsafat Pendidikan Islam. Jakarta: Bulan Bintang.

Ghazaly, I. a. (n.d.). Ihya Ulumiddin jilid 1. Kairo : Mathba'ah Shabih, tt),

Khasinah, S. (2013). Hahikat Manusia menurut Pandangan Islam dan Barat. Jurnal Ilmiah DIDAKTIKA Februari 2013, 296.

Langgulung, H. (1988). Beberapa Pemikiran tentang Pendidikan Islam. Jakarta: Pustaka Al-Husna.

Maghfiroh, L. (2019). HAKIKAT PENDIDIK DAN PESERTA DIDIK. MIDA: Jurnal Pendidikan Dasar Islam, 2019, 24.

Maisyaroh. (2019). Jurnal Pendidikan Agama Islam Al-Thariqah Vol. 4, No. 2, JuliDesember 2019, 6.

Maisyaroh. (2019). Jurnal Pendidikan Agama Islam Al-Thariqah Vol. 4, No. 2, JuliDesember 2019, 6.
Moleong, L. J. (1989). Metodologi Penelitian Kualitatif. Jakarta: Badan Litbangkes RI.

Muhammad., A. (2014). Hakikat pendidik dalam Pendidikan Islam. Jurnal Tarbawiyah Volume 11 Nomor 1 Edisi Januari-Juli, 84.

Mursyi, M. M. (1977). At-Tarbiyah al-Islamiyah: Ushuluha wa Tathawwuruha fi al-Bilad al-'Arabiya. Kairo: Alam al-Kutub.

Nahlawi, A. A. ( 2004). Pendidikan Islam di Rumah, Sekolah, dan Masyarakat terj. Shihabudin, . Jakarta: Gema Insani Press.

Naim, N. (2009). Menjadi Guru Inspiratif Memberdayakan dan Mengubah jalan Hidup Siswa. Yogyakarta: Pustaka Pelajar.

Nasihah, U. (2012, 12 senin). dalam http://makalahmajannaii.blogspot.com.

Retrieved from pendidik-dalampendidikan-islam.htm.

Nasihah, U. (2012, 12 Senin). pendidik-dalampendidikan-islam.html . Retrieved from dalam http://makalahmajannaii.blogspot.com.

Nata, A. (1997). Filsafat Pendidikan Islam. Jakarta: Logos Wacana Ilmu.

Nizar, A.-R. d. (2005). Pendekatan Historis, Teoritis, dan Praktis Filsafat Pendidikan Islam. Jakarta: Ciputat Press.

Ramayulis. (2005). Jakarta: Kalam Mulia.

Ramayulis. (2008). Jakarta: Kalam Mulia.

Ramli, M. (2015). "Hakikat Pendidik Dan Peserta Didik. " Tarbiyah Islamiyah: Jurnal Ilmiah Pendidikan Agama Islam 5.1, 61.

Ridla, M. J. (1980). Al-Fikr al-Tarbawi al-Islam. Mesir: Dar al-Fikr al-Arabi.

Roysadi, K. (2004). Pendidikan Profetik. Yogyakarta: Pustaka Pelajar.

Saputra, M. I. (2015). "Hakekat Pendidik Dan Peserta Didik Dalam Pendidikan Islam. At-Tazkiyah :Jurnal Pendidikan Islam 6.2, 231-251.

Shihab, Q. (2008). "Peningkatan Peranan dan Kualitas Pendidik Muslim dalam Pembentukan Karakter Bangsa". UNS Surakarta. Solo: UNS.

Soetjipto. (2009). Profesi Keguruan,. Jakarta: Rineka Cipta.

Suparlan. (2006). Guru Sebagai Profesi. Yogyakarta: Hikayat Publishing. 
Tarbiyah: Jurnal Ilmiah Kependidikan

Vol. 9 No. 1. January - June 2020 (42-50)

DOI: http://dx.doi.org/10.18592/tarbiyah.v9i1.3471

Suparno, P. ( 2004). Guru Demokratis di Era Reformasi . Jakarta: Grasindo.

Tafsir, A. (2006). Filsafat Pendidikan Islam. Bandung: Remaja Rosda Karya.

Turmizdy, I. a. (n.d.). Sunan At-Tarmizdy, Ma ja a fi fadhilatil fiqhi juz 10 halaman 207. Maktabah Syamilah.
Ulwan, A. N. (1999). Tarbiyatul Aulad fi alIslam: Pendidikan Anak dalam Islam, terjemah Jamaludin Miri . Jakarta: Pustaka Amani.

UU Nomor 20 tahun 2003 pasal 39. (n.d.). 